\title{
Production of dissolved organic matter by phytoplankton and its uptake by heterotrophic prokaryotes in large tropical lakes
}

\section{Cedric Morana, ${ }^{1, *}$ Hugo Sarmento, ${ }^{2,3}$ Jean-Pierre Descy, ${ }^{4}$ Josep M. Gasol, ${ }^{3}$ Alberto V. Borges, ${ }^{5}$ Steven Bouillon, ${ }^{1}$ and François Darchambeau ${ }^{5}$}

\author{
${ }^{1}$ Katholieke Universiteit Leuven (KU Leuven), Department of Earth and Environmental Sciences, Leuven, Belgium \\ ${ }^{2}$ Federal University of São Carlos (UFSCar), Department of Hydrobiology (DHb), São Carlos, Brazil \\ ${ }^{3}$ Institut de Ciències del Mar-Consejo Superior de Investigaciones Científicas (CSIC), Barcelona, Catalunya, Spain \\ ${ }^{4}$ Université de Namur, Research Unit in Environmental and Evolutionary Biology, Namur, Belgium \\ ${ }^{5}$ Université de Liège, Chemical Oceanography Unit, Liège, Belgium
}

\begin{abstract}
In pelagic ecosystems, phytoplankton extracellular release can extensively subsidize the heterotrophic prokaryotic carbon demand. Time-course experiments were carried out to quantify primary production, phytoplankton excretion, and the microbial uptake of freshly released dissolved organic carbon (DOC) derived from phytoplankton extracellular release (DOCp) in four large tropical lakes distributed along a productivity gradient: Kivu, Edward, Albert, and Victoria. The contributions of the major heterotrophic bacterial groups to the uptake of DOCp was also analyzed in Lake Kivu, using microautoradiography coupled to catalyzed reporter deposition fluorescent in situ hybridization. The percentage of extracellular release (PER) varied across the productivity gradient, with higher values at low productivity. Furthermore, PER was significantly related to high light and low phosphate concentrations in the mixed layer and was comparatively higher in oligotrophic tropical lakes than in their temperate counterparts. Both observations suggest that environmental factors play a key role in the control of phytoplankton excretion. Standing stocks of DOCp were small and generally contributed less than $1 \%$ to the total DOC because it was rapidly assimilated by prokaryotes. In other words, there was a tight coupling between the production and the heterotrophic consumption of DOCp. None of the major phylogenetic bacterial groups that were investigated differed in their ability to take up DOCp, in contrast with earlier results reported for standard labeled single-molecule substrates (leucine, glucose, adenosine triphosphate). It supports the idea that the metabolic ability to use DOCp is widespread among heterotrophic prokaryotes. Overall, these results highlight the importance of carbon transfer between phytoplankton and bacterioplankton in large African lakes.
\end{abstract}

In aquatic systems, the dissolved organic carbon (DOC) pool is a mixture of molecules in a continuum of biological lability, with components from different origins: allochthonous, in freshwaters mainly deriving from the watershed runoff, and autochthonous material produced in situ, such as DOC derived from phytoplankton extracellular release (DOCp) or cell lysis (Myklestad 2000). Both carbon (C) sources can be important to sustain the growth of heterotrophic prokaryotes, but bacteria are highly selective toward the substrate they use (Sarmento and Gasol 2012). In most aquatic systems, heterotrophic bacteria preferentially use labile freshly produced DOCp over more recalcitrant allochthonous compounds (Pérez and Sommaruga 2006). Positive correlations between particulate primary production ( $\mathrm{pPP}$ ) and bacterial production (BP) have been reported for many aquatic systems (Cole et al. 1988; Fouilland and Mostajir 2010). These observations have been used to demonstrate the dependence of heterotrophic bacteria on phytoplankton activity mediated by the release of DOCp. But both phytoplankton and bacterial populations might also be regulated by the same environmental factors, such as inorganic nutrient availability, and then might co-vary with no major interaction (Fouilland and Mostajir 2010). One way to test the interaction strength between primary producers and

* Corresponding author: cedric.morana@ees.kuleuven.be bacteria is to measure the phytoplankton production of DOCp (dissolved primary production; dPP) and the kinetics of its uptake by heterotrophic prokaryotes (Morán et al. 2001; Sarmento and Gasol 2012).

Despite its relevance in ecosystem studies, measurements of dPP are scarce, especially in freshwater ecosystems. Based on a literature review, Baines and Pace (1991) proposed an average cross-system percentage of extracellular release (PER) of $13 \%$ of total C fixation. However, when comparing freshwater and marine data, it was observed that PER in marine systems was constant across the productivity gradient; whereas, in temperate freshwaters, PER was inversely related to productivity (Baines and Pace 1991). A similar inverse relation in temperate freshwater was found in the recent literature review by Fouilland and Mostajir (2010). There is an ongoing debate about whether DOCp release is an overflow mechanism, whereby DOCp is actively released by healthy phytoplankton cells and is, therefore, constrained by the availability of photosynthates (Fogg 1983; Baines and Pace 1991; Morán and Estrada 2002), or whether DOCp release is a purely passive physiological mechanism, directly proportional to phytoplankton biomass (Bjørnsen 1988; Marañón et al. 2004). Several environmental factors affect PER rates, such as nutrient availability (Obernosterer and Herndl 1995), light conditions (Fogg 1983), and temperature (Zlotnik and Dubinsky 1989); but no consensus has been achieved so far 


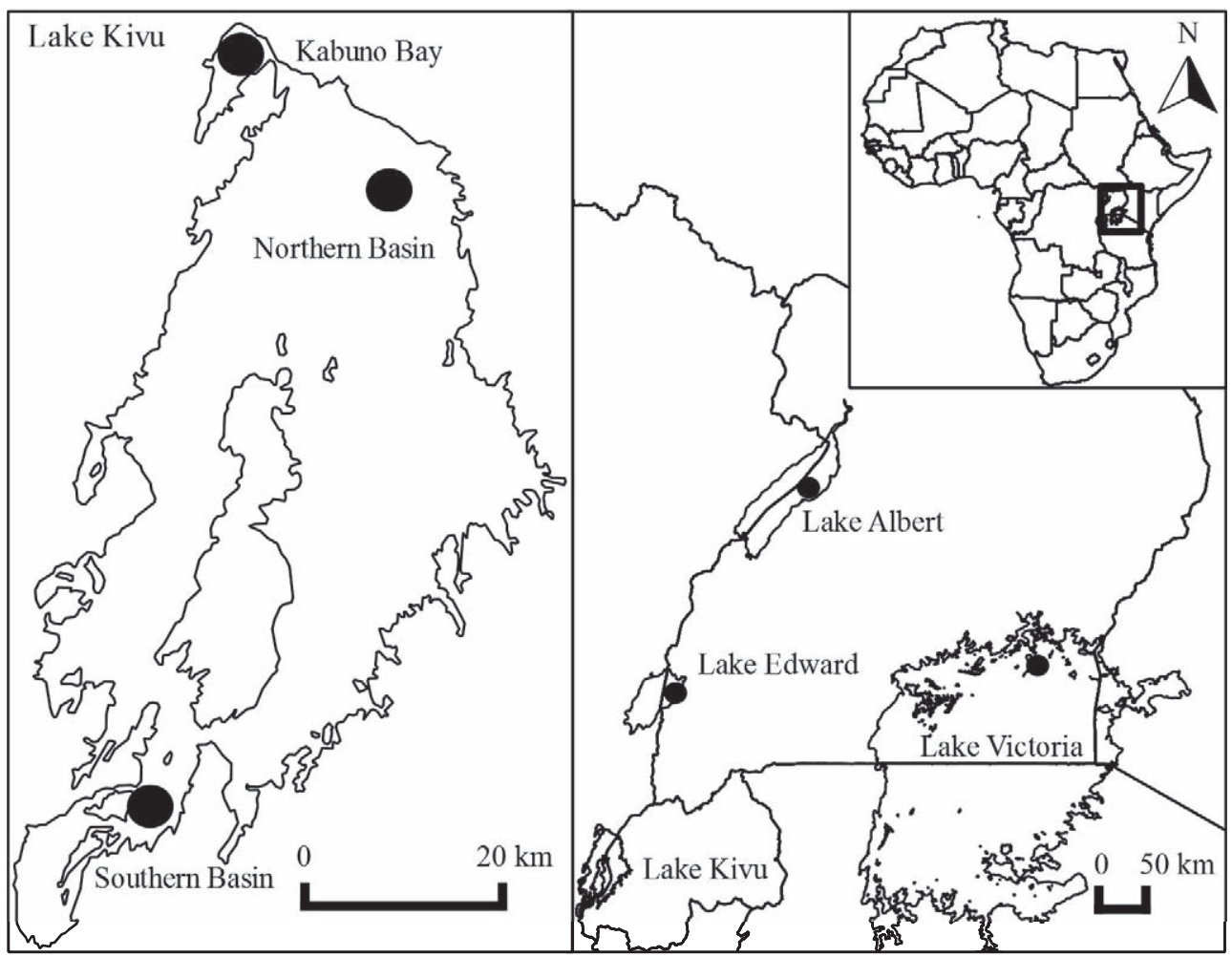

Fig. 1. Map of lakes Kivu, Albert, Edward, and Victoria, showing the location of the sampling sites (black circle) in April 2009, October 2010, and June 2011 in Lake Kivu, and in May 2012 in lakes Edward, Albert, and Victoria.

on the key environmental factors that determine the importance of PER and on how PER varies in the function of each one of these factors.

The aims of this study were to quantify dPP and the subsequent microbial uptake of DOCp in several large tropical lakes and to elucidate whether the PER was constant, or not, across a range of productivity. Due to the constant exposure to low-nutrient and high-light conditions over long periods of time in oligotrophic tropical lakes, we expected a strong coupling between phytoplankton and heterotrophic prokaryotes through high DOCp release. We performed several time-course experiments of radiocarbon incorporation into dissolved and particulate organic pools, which allowed for correction for heterotrophic uptake of DOCp during the experiments. Furthermore, in one of our study sites (Lake Kivu), we applied the microautoradiography coupled with catalyzed reporter deposition fluorescence in situ hybridization (MAR-FISH) technique to assess the extent to which different groups of heterotrophic prokaryotes were active in the uptake of $\mathrm{DO}^{14} \mathrm{Cp}$ released by the natural phytoplankton communities and of ${ }^{3} \mathrm{H}$-leucine, a widely used tracer for BP measurements (Kirchman et al. 1985).

\section{Methods}

Study site and water sampling-Data were obtained in large East African lakes Kivu, Edward, Albert, and Victoria (Fig. 1). Sampling in Lake Kivu was conducted in the main lake (northern basin $01^{\circ} 43^{\prime} \mathrm{S}, 29^{\circ} 14^{\prime} \mathrm{E}$; southern basin $\left.02^{\circ} 20^{\prime} \mathrm{S}, 28^{\circ} 58^{\prime} \mathrm{E}\right)$ and in Kabuno Bay $\left(01^{\circ} 37^{\prime} \mathrm{S}\right.$, $29^{\circ} 02^{\prime} \mathrm{E}$ ) in April 2009 (late rainy season), October 2010 (rainy season), and June 2011 (dry season; Fig. 1). Both systems are meromictic but differ in terms of morphometry, with a shallower permanent chemocline in Kabuno Bay compared to the main lake (Borges et al. 2011). Lakes Edward $\left(00^{\circ} 12^{\prime} \mathrm{N}, 29^{\circ} 49^{\prime} \mathrm{E}\right)$, Albert $\left(01^{\circ} 48^{\prime} \mathrm{N}, 31^{\circ} 16^{\prime} \mathrm{E}\right)$, and Victoria $\left(00^{\circ} 33^{\prime} \mathrm{N}, 33^{\circ} 16^{\prime} \mathrm{E}\right)$ were sampled in May 2012. They are shallower than Lake Kivu and are holomictic; consequently, chlorophyll $a(\mathrm{Chl} a)$ concentrations are usually higher in their mixed layer. General limnological characteristics of the four lakes are provided in Table 1 .

Sampling procedure-The mixed-layer depth was determined at each occasion, based on in situ observed vertical profiles of temperature and oxygen obtained with a Yellow Springs Instruments $6600 \mathrm{v} 2$ multiparameter probe. Water was collected with a 7 liter Niskin bottle (Hydro-Bios) at a depth interval of $5 \mathrm{~m}$ from the surface to the bottom of the mixed layer and was then pooled to obtain a representative sample of the mixed layer. The vertical light attenuation coefficient, $\mathrm{K}\left(\mathrm{m}^{-1}\right)$, was calculated from simultaneous measurements of surface irradiance with a Li-Cor LI-190 quantum sensor and underwater photosynthetically active radiation (PAR) measurements with a submersible Li-Cor LI-193SA spherical quantum sensor. K was derived from the slope of the semi-logarithmic regression between relative 
Table 1. General limnological characteristics of the lakes investigated.

\begin{tabular}{|c|c|c|c|c|c|}
\hline & $\begin{array}{c}\text { Lake Kivu } \\
\text { (main lake) }\end{array}$ & $\begin{array}{c}\text { Lake Kivu } \\
\text { (Kabuno Bay) }\end{array}$ & Lake Edward & Lake Albert & Lake Victoria \\
\hline Lake area $\left(\mathrm{km}^{2}\right)$ & 2322 & 48 & 2325 & 5300 & 68800 \\
\hline Catchment area $\left(\mathrm{km}^{2}\right)$ & 4613 & 3 & 15840 & 17000 & 195000 \\
\hline Maximum depth (m) & 485 & 120 & 117 & 58 & 79 \\
\hline Mean depth (m) & 245 & 65 & 40 & 25 & 40 \\
\hline Mixing regime & Meromictic & Meromictic & Holomictic & Holomictic & Holomictic \\
\hline Mixed layer temperature $\left({ }^{\circ} \mathrm{C}\right)$ & $23.0-24.5^{*}$ & $22.5-24.5^{*}$ & $25.2-27.2 \dagger$ & $27.4-29.0 \dagger$ & $25.2-27.7+$ \\
\hline Mean Chl $a\left(\mathrm{mg} \mathrm{m}^{-3}\right)$ & $2.2 \S$ & $2.6^{*}$ & $5-10$ & $13-60+$ & $26.5^{\circ}$ \\
\hline Mean TP concentration $(\mu \mathrm{mol} \mathrm{L}-1)$ & $0.6^{*}$ & $1.0^{*}$ & $1.4 \mid$ & 2.5 & $2.5 \uparrow$ \\
\hline Mean euphotic depth $1 \%(\mathrm{~m})$ & $18 \S$ & $10^{*}$ & $13 \mid$ & $6-12 \dagger$ & $9+$ \\
\hline
\end{tabular}

* This study.

$\dagger$ Verbeke 1957.

$\$$ R. Mugidde unpubl.

$\S$ Darchambeau et al. 2014

I Lehman et al. 1998.

- Guildford and Hecky 2000.

quantum irradiance and depth. The mean irradiance in the mixed layer $\left(\mathrm{I}_{\mathrm{Zm}}\right)$ was calculated following Riley (1957):

$$
\mathrm{I}_{\mathrm{Zm}}=\mathrm{I}_{0} \times\left(1-e^{-\mathrm{K} \times \mathrm{Zm}}\right) /(\mathrm{K} \times \mathrm{Zm})
$$

where $\mathrm{I}_{0}$ is the incident irradiance at the surface $(\mu \mathrm{mol}$ photon $\left.\mathrm{m}^{-2} \mathrm{~s}^{-1}\right), \mathrm{K}\left(\mathrm{m}^{-1}\right)$ is the vertical light attenuation coefficient, and $\mathrm{Zm} \mathrm{(m)} \mathrm{is} \mathrm{the} \mathrm{mixed-layer} \mathrm{depth.}$

Chemical analyses-Phosphate $\left(\mathrm{PO}_{4}^{3-}\right)$ concentrations were quantified spectrophotometrically following standard procedures (American Public Health Association 1998). Measurements of $\mathrm{pH}$ were carried out with a Metrohm (6.0253.100) combined electrode calibrated with U.S. National Bureau of Standards buffers of $\mathrm{pH} 4.002\left(25^{\circ} \mathrm{C}\right)$ and $\mathrm{pH} 6.881\left(25^{\circ} \mathrm{C}\right)$, prepared according to Frankignoulle and Borges (2001). Measurements of total alkalinity (TA) were carried out by open-cell titration with $\mathrm{HCl} 0.1 \mathrm{~mol} \mathrm{~L}^{-1}$ on $50 \mathrm{~mL}$ water samples, and data were quality checked with Certified Reference Material acquired from Andrew Dickson (Scripps Institution of Oceanography, University of California, San Diego). Typical precision for TA measurements was better than $\pm 3 \mu \mathrm{mol} \mathrm{L}^{-1}$. Dissolved inorganic carbon (DIC) was computed from $\mathrm{pH}$ and TA measurements, using the carbonic acid dissociation constants of Millero et al. (2006). Water samples for DOC concentrations were filtered through preflushed $0.2 \mu \mathrm{m}$ syringe filters in $40 \mathrm{~mL}$ borosilicate vials with Tefloncoated screw caps and were preserved with $0.1 \mathrm{~mL}$ of $\mathrm{H}_{3} \mathrm{PO}_{4}(50 \%)$. DOC concentrations were measured with a customized Thermo Hipertoc coupled to a Delta+XL isotope ratio mass spectrometer, whereby complete oxidation of the sample is ensured by a combination of sodium persulfate addition, heating, and ultraviolet radiation. Quantification and calibration was performed with a standard solution of sucrose purchased from the International Atomic Energy Agency (IAEA-C6). Typical reproducibility for DOC analyses was on the order of $<5 \%$.

Chl a concentration - $\mathrm{Chl} a$ concentrations were determined by high-performance liquid chromatography
(HPLC). At each sampling site, 3 liters of water from the mixed layer pool was filtered on a Macherey-Nägel GF-5 filter (nominal porosity of $0.4 \mu \mathrm{m}$ ). Pigment extraction was carried out in $10 \mathrm{~mL}$ of $90 \%$ HPLC grade acetone. After two sonication steps of 15 min separated by an overnight period at $4^{\circ} \mathrm{C}$, the extracts were stored in $2 \mathrm{~mL}$ amber vials at $-25^{\circ} \mathrm{C}$. HPLC analysis was performed following the method described in Sarmento et al. (2008), with a Waters system comprising a photodiode array and fluorescence detectors. Calibration was made using commercial external standards (DHI Lab Products). Precision for Chl $a$ measurement was better than $\pm 7 \%$.

$p P P$ and $d P P$ and heterotrophic uptake of freshly excreted compounds - $\mathrm{pPP}$ and microbial uptake are usually estimated by tracing the incorporation of a radioactive tracer $\left({ }^{14} \mathrm{C}\right)$ into two different size fractions representing phytoplankton $(>2 \mu \mathrm{m})$ and heterotrophic prokaryotes $(<2 \mu \mathrm{m}$; Cole et al. 1982). However, the important contribution of picophytoplankton $(<2 \mu \mathrm{m})$ to total phytoplankton biomass in some African lakes $(21 \%$ in Lake Kivu; Sarmento et al. 2008) complicates the physical separation of the primary producers from heterotrophic prokaryotes by such a size-selective filtration. This problem may be overcome by measurement of the time-course incorporation of ${ }^{14} \mathrm{C}$ into the dissolved $(<0.2 \mu \mathrm{m})$ and particulate $(>0.2 \mu \mathrm{m})$ phase, the latter including both heterotrophic prokaryotes and phytoplankton (Morán et al. 2001; Morán and Estrada 2002). Results are then modeled by a compartmental organic $\mathrm{C}$ exchange model, extensively described by Morán and Estrada (2002), and are briefly summarized in the next section. Due to the importance of picophytoplankton in some lakes studied, this approach was preferred for this study.

In the field, aliquots of $40 \mathrm{~mL}$ of water from the mixedlayer pool were introduced in transparent $70 \mathrm{~mL}$ sterile polycarbonate cell culture flasks. Each bottle was spiked with $62.5 \mu \mathrm{Ci}$ of $\mathrm{NaH}^{14} \mathrm{CO}_{3}$ (specific activity of 40 $60 \mathrm{mCi} \mathrm{mmol}^{-1}$; Perkin Elmer) and then was incubated at in situ temperature under a constant PAR of $200 \mu \mathrm{mol}$ photon $\mathrm{m}^{-2} \mathrm{~s}^{-1}$ provided by a Philips fluorescent lamp (PL 
Table 2. Mixed-layer depth $(\mathrm{Zm} ; \mathrm{m})$, mean daylight irradiance in the mixed layer $\left(\mathrm{I}_{\mathrm{Zm}} ; \mu \mathrm{mol}\right.$ photon $\left.\mathrm{m}^{-2} \mathrm{~s}^{-1}\right)$, particulate and dissolved primary production ( $\mathrm{pPP}$ and $\mathrm{dPP} ; \mathrm{mg} \mathrm{C} \mathrm{m}^{-3} \mathrm{~h}^{-1}$ ), percentage of extracellular release (PER; \%), concentrations of Chl $a$ $\left(\mathrm{mg} \mathrm{m}^{-3}\right)$, dissolved organic carbon $\left(\mathrm{DOC} ; \mathrm{mg} \mathrm{C} \mathrm{m}^{-3}\right)$, freshly excreted dissolved organic carbon $\left(\mathrm{DOCp} ; \mathrm{mg} \mathrm{C} \mathrm{m}^{-3}\right)$, and $\mathrm{DOCp}$ turnover times (h) in lakes Kivu (Southern bay, Northern bay, Kabuno Bay), Edward, Albert, and Victoria.

\begin{tabular}{|c|c|c|c|c|c|c|c|c|c|c|}
\hline Station & Year & $\mathrm{Z}_{\mathrm{m}}$ & $\mathrm{I}_{\mathrm{Zm}}$ & $\mathrm{pPP}$ & $\mathrm{dPP}$ & PER & Chl $a$ & $\mathrm{DOC}$ & DOCp & Turnover DOCp \\
\hline Southern bay & 2009 & 20 & 220 & 0.8 & 1.1 & 57 & 1.9 & 1967 & 1.7 & 1.5 \\
\hline Southern bay & 2010 & 12.5 & 381 & 2.8 & 2.8 & 50 & 2.1 & 1924 & 3.6 & 1.3 \\
\hline Southern bay & 2011 & 30 & 186 & 1.7 & 3.0 & 64 & 2.1 & 1757 & 3.9 & 1.3 \\
\hline Northern bay & 2009 & 22.5 & 249 & 1.6 & 2.6 & 62 & 1.2 & 1911 & 6.4 & 2.1 \\
\hline Northern bay & 2010 & 22.5 & 243 & 4.0 & 3.9 & 49 & 2.3 & 1872 & 2.3 & 0.6 \\
\hline Northern bay & 2011 & 42.5 & 76 & 2.9 & 2.7 & 48 & 2.0 & 1709 & 3.6 & 1.3 \\
\hline Kabuno Bay & 2009 & 10 & 162 & 3.9 & 3.9 & 50 & 2.4 & 2341 & 8.3 & 2.5 \\
\hline Kabuno Bay & 2011 & 5 & 265 & 5.1 & 3.7 & 42 & 2.6 & 1779 & 13.2 & 3.6 \\
\hline Lake Edward & 2012 & 7.5 & 145 & 26.8 & 6.5 & 20 & 9.9 & 4757 & 5.5 & 0.8 \\
\hline Lake Albert & 2012 & 20 & 95 & 27.4 & 5.9 & 18 & 5.4 & 4383 & 3.6 & 0.6 \\
\hline Lake Victoria & 2012 & 15 & 108 & 172.7 & 9.4 & 5 & 5.1 & 1807 & 102.3 & 10.9 \\
\hline
\end{tabular}

55W Daylight DeLuxe). This light intensity was close to the mean $I_{\mathrm{Zm}}$ of the investigated lakes at the time of the experiments (Table 2) and to the saturation irradiance value $\left(\mathrm{I}_{\mathrm{k}}\right)$ reported for Lake Kivu $(318 \mu$ mol photon $\mathrm{m}^{-2} \mathrm{~s}^{-1}$; Darchambeau et al. 2014). The incubations lasted for 5-6 h, and, at 30 or 60 min intervals, biological activity was stopped by adding neutral formaldehyde $(0.02 \%$ final concentration) into two transparent flasks. Two additional flasks covered with aluminum foil were processed in the same manner immediately at the beginning and at the end of the experiment, providing a dark incorporation control. The bottles were then kept overnight at $4^{\circ} \mathrm{C}$ before subsequent processing. From each flask, a $20 \mathrm{~mL}$ subsample was filtered under low-pressure vacuum on membrane filters (Millipore GSWP; $0.22 \mu \mathrm{m}$ nominal porosity) to separate the particulate from the dissolved fraction. In order to remove the labeled inorganic $\mathrm{C}\left(\mathrm{DI}{ }^{14} \mathrm{C}\right)$, liquid samples $\left(\mathrm{DO}^{14} \mathrm{C}\right)$ were acidified with $1 \mathrm{~mL}$ of $\mathrm{HCl}$ $\left(6 \mathrm{~mol} \mathrm{~L}{ }^{-1}\right)$ and were left open overnight in an orbital shaker, and filters $\left(\mathrm{PO}^{14} \mathrm{C}\right)$ were fumed overnight with

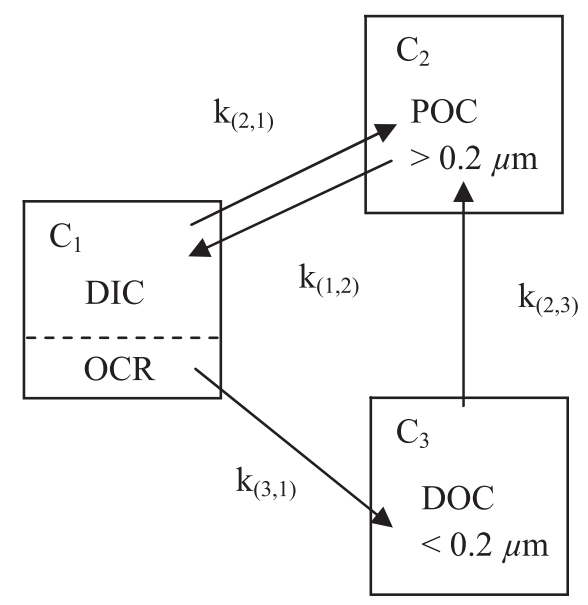

Fig. 2. Schematic representation of the three-compartment model applied on the experimental data. DIC $=$ dissolved inorganic carbon, $\mathrm{DOC}=$ dissolved organic carbon, $\mathrm{POC}=$ particulate organic carbon, $\mathrm{OCR}=$ intracellular pool of organic carbon fated for release pool; see text and Morán et al. (2001) for further details. concentrated $\mathrm{HCl}$. Radioactivity of the filters and liquid samples was measured using a Packard Tri-Carb Liquid Scintillation Counter with Ultima Gold (Perkin Elmer) as scintillation cocktail and the external standard method for quench correction. $\mathrm{T}_{0}$ values were subtracted from values of subsequent samples in order to correct for the abiotic radiocarbon incorporation. The radioactivity values in dark incorporation control bottles at the end of every experiment were never significantly different than values in the respective $\mathrm{T}_{0}$-bottles; therefore, they were not subtracted.

Organic C exchange model-Assuming steady state, the experimental results were fitted with a three-compartment model of organic $\mathrm{C}$ exchange, extensively described in Morán et al. (2001) and Morán and Estrada (2002). The rate of change of the radiocarbon content in the three different compartments is described by the following equations (Fig. 2):

$$
\begin{aligned}
& \mathrm{dC}_{1} / \mathrm{dt}=-\mathrm{k}_{(2,1)} \times \mathrm{C}_{1}+\mathrm{k}_{(1,2)} \times \mathrm{C}_{2}-\mathrm{k}_{(3,1)} \times \mathrm{C}_{1} \\
& \mathrm{dC}_{2} / \mathrm{dt}=\mathrm{k}_{(2,1)} \times \mathrm{C}_{1}-\mathrm{k}_{(1,2)} \times \mathrm{C}_{2}+\mathrm{k}_{(2,3)} \times \mathrm{C}_{3} \\
& \mathrm{dC}_{3} / \mathrm{dt}=\mathrm{k}_{(3,1)} \times \mathrm{C}_{1}-\mathrm{k}_{(2,3)} \times \mathrm{C}_{3}
\end{aligned}
$$

where $\mathrm{C}_{1}$ is the radiocarbon concentration in the DIC pool, $\mathrm{C}_{2}$ is the radiocarbon concentration in the particulate organic carbon (POC) pool, and $\mathrm{C}_{3}$ is the radiocarbon concentration in the DOC pool; $\mathrm{k}_{(\mathrm{i}, \mathrm{j})}$ is the rate constant of $\mathrm{C}$ flux from pool $\mathrm{j}$ to pool $\mathrm{i}\left(\mathrm{in}^{-1}\right)$. Hence, $\mathrm{k}_{(2,1)}$ is the rate constant of $\mathrm{pPP}, \mathrm{k}_{(1,2)}$ is the rate constant of respiration of synthesized POC, inferred from its influence on the $\mathrm{PO}^{14} \mathrm{C}$ kinetics, $\mathrm{k}_{(3,1)}$ is the rate constant of phytoplankton excretion or $\mathrm{dPP}$, and $\mathrm{k}_{(2,3)}$ is the rate constant of heterotrophic uptake of freshly produced DOCp.

A striking particularity of the model lies in the origin of the DOCp production flux. Although it is obvious that DOCp should first be incorporated by phytoplankton before its excretion, the model considers the DOCp to be directly produced from a subcompartment integrated into the DIC pool, the organic $\mathrm{C}$ fated for release (OCR) pool. This subcompartment is defined as an intracellular 
phytoplankton C pool of organic compounds and is assumed to be quasi-instantaneously in isotopic equilibrium with the DIC pool (Morán et al. 2001; Morán and Estrada 2002). This assumption was confirmed experimentally, for example, by the absence of any lag phase in $\mathrm{DO}^{14} \mathrm{C}$ kinetic curve when phytoplankton incorporates labeled-DIC (Wiebe and Smith 1977; our own results below).

Least-squares nonlinear fitting of the model to dissolved $\left(\mathrm{DO}^{14} \mathrm{C}\right)$ and particulate $\left(\mathrm{PO}^{14} \mathrm{C}\right)$ radioactivity measurement was performed using Saam II software (Epsilon Group). Data were weighted by the inverse of the standard deviation of duplicates. The pPP and dPP rates were respectively calculated from $\mathrm{k}_{(2,1)}$ and $\mathrm{k}_{(3,1)}$ multiplied by the DIC concentration. PER (\%) was calculated as:

$$
\mathrm{PER}=\mathrm{dPP} /(\mathrm{pPP}+\mathrm{dPP}) \times 100
$$

MAR-FISH-MAR-FISH allows tracking at the singlecell level of substrate uptake by heterotrophic organisms. We investigated the heterotrophic uptake of two types of substrate: ${ }^{3} \mathrm{H}$-leucine, a widely used tracer for bulk BP measurements (Kirchman et al. 1985), and an uncharacterized mixture of $\mathrm{DO}^{14} \mathrm{Cp}$ produced by natural lake water phytoplankton assemblages during the experiment. In 2011, in parallel to the dPP experiments carried out in Kabuno Bay and in the southern basin of Lake Kivu, four supplementary culture flasks were filled with $20 \mathrm{~mL}$ of water from the mixed layer pool and were spiked with $62.5 \mu \mathrm{Ci}$ of $\mathrm{NaH}^{14} \mathrm{CO}_{3}$. Two of these flasks were incubated for $5 \mathrm{~h}$ under a constant PAR as described above, whereas the two others were covered with aluminum foil and were incubated in the dark, in order to correct for bacterial DI ${ }^{14} \mathrm{C}$ uptake. The isotopic equilibrium between the DIC and DOCp pool was reached before the end of the $5 \mathrm{~h}$ incubations, and the specific activity of the $\mathrm{DO}^{14} \mathrm{Cp}$ was $258 \mu \mathrm{Ci} \mathrm{mmol}{ }^{-1}$. Finally, two additional culture flasks were spiked with ${ }^{3} \mathrm{H}$-leucine $\left(0.5 \mathrm{nmol} \mathrm{L}{ }^{-1}\right.$ final concentration; specific activity $162 \mathrm{Ci} \mathrm{mmol}^{-1}$ ) and were kept in the dark for $5 \mathrm{~h}$. Incubations were stopped by adding neutral formaldehyde (1.8\% final concentration), and the samples were stored overnight at $4^{\circ} \mathrm{C}$, followed by gentle filtration of $5 \mathrm{~mL}$ on a $0.2 \mu \mathrm{m}$ isopore membrane polycarbonate filter (Millipore). Filters were then stored at $-20^{\circ} \mathrm{C}$ until further processing.

Catalyzed reporter fluorescent in situ hybridization (CARD-FISH) analyses were carried out as follows. The cells were permeabilized with lyzozyme and achromopeptidase prior to the hybridization. Several horseradish peroxidase (HRP)-probes were used to characterize the composition of the bacterial community in the water samples, using the procedure described by Alonso-Sáez and Gasol (2007). The HRP-labeled probes used were EUB338-II -III (targets most Eubacteria), GAM42a (targets most Gammaproteobacteria), BET42a (targets most Betaproteobacteria), ALF968 (targets most Alphaproteobacteria), and CF319 (targets many groups belonging to Bacteroidetes). The unlabeled competitors BET42a for GAM42a and GAM42a for BET42a were used. Specific hybridization conditions were established by adding formamide to the hybridization buffer (45\% formamide for ALF968, 55\% for the other probes). All probes were purchased from Biomers. Counterstaining of CARD-FISH preparations was done with 4,6 diamidino-2-phenylindole (DAPI; final concentration $1 \mu \mathrm{g} \mathrm{mL}^{-1}$ ). Between 500 and 1000 DAPI-positive cells were counted with an Olympus BX61 epifluorescence microscope in a minimum of 10 fields.

MAR-FISH analyses were performed after hybridization following the CARD-FISH protocol. The filters were glued onto glass slides with an epoxy adhesive (Uhu plus). The slides were embedded in $46^{\circ} \mathrm{C}$ tempered photographic emulsion (Kodak NTB-2) containing 0.1\% agarose (gel strength $1 \%,>1 \mathrm{~kg} \mathrm{~cm}^{-2}$ ) and were placed in a dark room on an ice-cold metal bar for about 5 min to allow the emulsion to solidify. They were subsequently placed inside black boxes at $4{ }^{\circ} \mathrm{C}$ until development. Based on preliminary trials, we used an optimal exposure time of $7 \mathrm{~d}$ for samples incubated with ${ }^{3} \mathrm{H}$-leucine and $10 \mathrm{~d}$ for samples incubated with $\mathrm{DO}^{14} \mathrm{Cp}$. For development, exposed slides were submerged for $3 \mathrm{~min}$ in a developer (Kodak D-19), rinsed $30 \mathrm{~s}$ with distilled water, and then placed for $3 \mathrm{~min}$ in a fixer (Kodak T-max), followed by 5 min of washing with tap water. The slides were then dried in a dessicator overnight, stained with DAPI $\left(1 \mu \mathrm{g} \mathrm{mL}^{-1}\right)$, and inspected under an Olympus BX61 epifluorescence microscope. CARD-FISH positive cells (hybridized with the specific probe) appear in bright green under blue light excitation. Additionally, MAR-FISH positive cells contain dark silver grains accumulated above the bacterial cells on the radiographic emulsion, resulting from radioactive decay of labeled substrates.

\section{Results}

$d P P$ and $p P P$ and bacterial uptake of DOCp-The kinetics of incorporation of labeled substrate in the POC and DOC pools followed two distinct patterns (Fig. 3a,b). In all experiments, the radioactivity increased in the POC pool almost linearly with time, whereas the increase of radioactivity in the DOC pool was initially linear but rapidly leveled off at a maximum value after $2-4 \mathrm{~h}$.

The measured $\mathrm{pPP}$ rates in Lake Kivu ranged from $0.8 \mathrm{mg} \mathrm{C} \mathrm{m}^{-3} \mathrm{~h}^{-1}$ to $5.1 \mathrm{mg} \mathrm{C} \mathrm{m}^{-3} \mathrm{~h}^{-1}$, and the $\mathrm{dPP}$ rates from $1.1 \mathrm{mg} \mathrm{C} \mathrm{m}^{-3} \mathrm{~h}^{-1}$ to $3.9 \mathrm{mg} \mathrm{C} \mathrm{m}^{-3} \mathrm{~h}^{-1}$ (Table 2). Normalized to $\mathrm{Chl} a$, the total primary production ( $\mathrm{dPP}+$ pPP) in Lake Kivu averaged $2.8 \pm 0.8 \mathrm{mg} \mathrm{C} \mathrm{mg} \mathrm{Chl}$ $a^{-1} \mathrm{~h}^{-1}$. PER values ranged between $42 \%$ and $64 \%$, with an average of 53\%. Higher rates of pPP and dPP, but lower PER values, were found in lakes Edward, Albert, and Victoria (Table 2). Volumetric rates of pPP and dPP were positively correlated with $\mathrm{Chl} a$ concentration (Table 3; Fig. 4a,b). Furthermore, dPP was positively correlated to pPP, and the slopes of the model I and model II linear regressions were both significantly lower than 1 (Table 3; Fig. 5), implying that PER decreased with increasing primary production rates.

The turnover time of the DOCp in surface waters, calculated as the inverse of the $\mathrm{k}_{(2,3)}$ constant rate, ranged between $0.6 \mathrm{~h}$ and $3.6 \mathrm{~h}$, with an average of $1.8 \pm 0.9 \mathrm{~h}$ in Lake Kivu. The turnover time of DOCp was in the same 

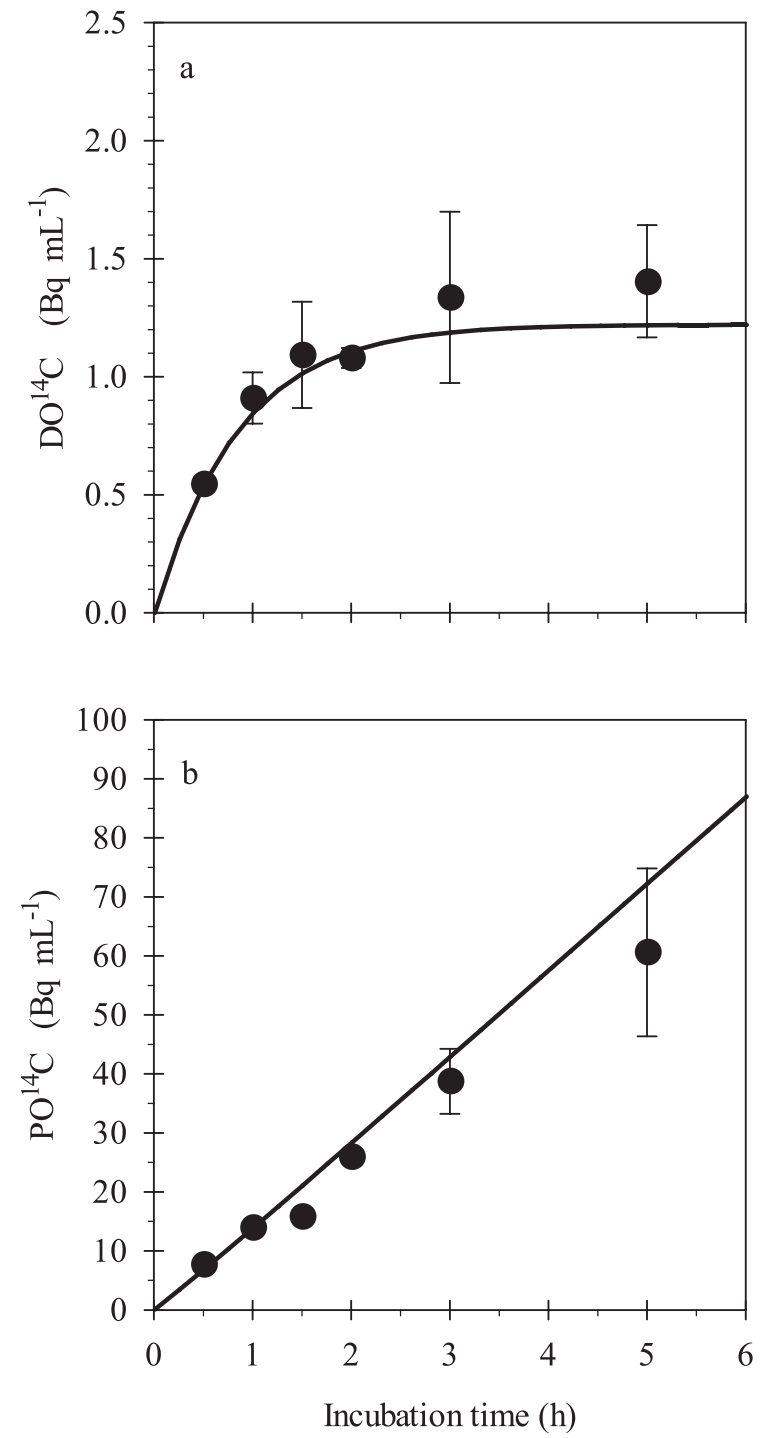

Fig. 3. Example of the kinetics of phytoplankton production of (a) $\mathrm{DO}^{14} \mathrm{C}$ and (b) $\mathrm{PO}^{14} \mathrm{C}$ during $5 \mathrm{~h}$ of incubation in Lake Edward. The fitted curves are derived from the three-compartment model presented in Fig. 2. Symbols are mean of duplicate measurements, and error bars are maximum and minimum values.

range in lakes Edward $(0.8 \mathrm{~h})$ and Albert $(0.6 \mathrm{~h})$ but was clearly higher in the eutrophic Lake Victoria $(10.9 \mathrm{~h}$; Table 2). The size of the DOCp pool, calculated as the dPP rate multiplied by the turnover time of DOCp, ranged between $1.7 \mathrm{mg} \mathrm{C} \mathrm{m}^{-3}$ and $13.2 \mathrm{mg} \mathrm{C} \mathrm{m}^{-3}$ (but with a higher value of $102.3 \mathrm{mg} \mathrm{C} \mathrm{m}^{-3}$ for Lake Victoria), and contributed less than $1 \%$ to the DOC pool in lakes Kivu,
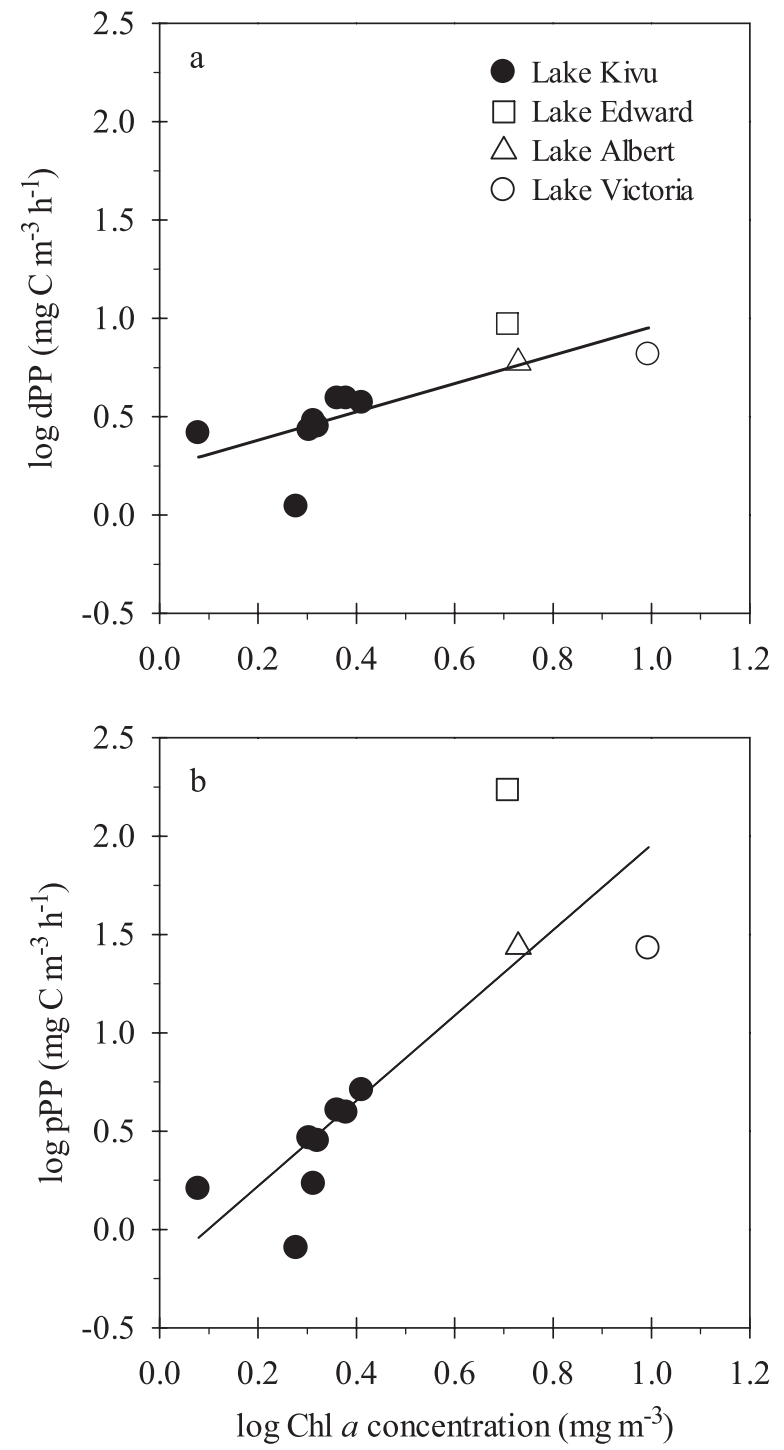

Fig. 4. Relationships between $\log (\mathrm{Chl} a)$ and (a) $\log (\mathrm{dPP})$ or (b) $\log (\mathrm{pPP})$ in lakes Kivu, Edward, Albert, and Victoria. Continuous lines illustrate model I linear regression lines.

Edward, and Albert, and approximately 5\% in Lake Victoria (Table 2).

${ }^{3} \mathrm{H}$-leucine and $\mathrm{DO}^{14} \mathrm{Cp}$ uptake by different bacterial phylogenetic groups-The bacterial community structure and the percentage of active cells taking up ${ }^{3} \mathrm{H}$-leucine and $\mathrm{DO}^{14} \mathrm{Cp}$ were investigated in 2011 in the southern basin of Lake Kivu and in Kabuno Bay, where, respectively, 75\%

Table 3. Summary of model I and model II log-log linear regressions between particulate and dissolved primary production (respectively, pPP and $\mathrm{dPP}$ ) and between pPP and Chl $a$. In parentheses, 95\% confidence interval.

\begin{tabular}{cccccccc}
\hline \hline & & & \multicolumn{3}{c}{ Model I regression } & & Model II regression \\
\cline { 4 - 6 } \cline { 4 - 6 }$y$ & $x$ & $n$ & Slope & Intercept & $R^{2}$ & $p$ & Slope \\
\hline $\log (\mathrm{pPP})$ & $\log (\mathrm{Chl} a)$ & 11 & $2.16(1.05,3.27)$ & $-0.21(-0.77,0.35)$ & 0.68 & $<0.05$ & $2.10(1.79,2.41)$ \\
$\log (\mathrm{dPP})$ & $\log (\mathrm{Chl} a)$ & 11 & $0.07(0.01,0.12)$ & $0.37(0.11,0.56)$ & 0.46 & $<0.05$ & \\
$\log (\mathrm{dPP})$ & $\log (\mathrm{pPP})$ & 11 & $0.33(0.23,0.44)$ & $0.31(0.23,0.44)$ & 0.85 & $<0.0001$ & $0.33(0.25,0.43)$ \\
\hline
\end{tabular}




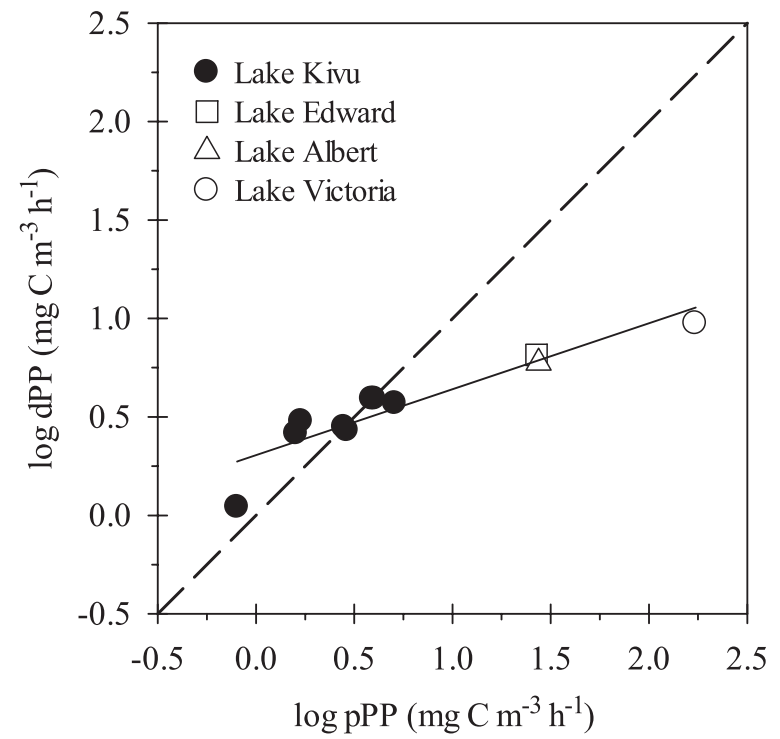

Fig. 5. Relationship between $\log (\mathrm{pPP})$ and $\log (\mathrm{dPP})$ in lakes Kivu, Edward, Albert, and Victoria. Continuous line illustrates model I linear regression line; dashed line is the 1:1 line.

and $83 \%$ of total cells counts were hybridized with EUB338-II-III probe (EUB, Eubacteria cells; Fig. 6). Members of Alphaproteobacteria, Betaproteobacteria, Gammaproteobacteria, and Bacteroidetes jointly comprised $49 \%$ and $50 \%$ of the total cell count and covered $65 \%$ and $60 \%$ of the bacterial domain in the southern basin and Kabuno Bay, respectively. Bacterial community structure, at the large group level targeted by CARDFISH probes, was fairly similar between the two sites (Fig. 6). After $5 \mathrm{~h}$ of incubation in the dark with ${ }^{3} \mathrm{H}$ leucine, $21 \%$ and $17 \%$ of the Eubacteria cells were found to take up ${ }^{3} \mathrm{H}$-leucine in the southern basin and Kabuno Bay, respectively. Of the Eubacteria cells, $12 \%$ and $11 \%$ were labeled at the end of the incubation when considering $\mathrm{DO}^{14} \mathrm{Cp}$ uptake. In the two stations, we found that less than $1 \%$ of the EUB338 cells were labeled by $\mathrm{DI}^{14} \mathrm{C}$; therefore, bacterial DIC fixation via chemoautotrophic or anapleurotic pathways seemed to have been insignificant in the surface waters of Lake Kivu during these short-term incubations.

By comparing the relative contribution of each bacterial group in substrate uptake with its relative abundance (Fig. 7a,b), we can examine whether these broad bacterial groups participated in the $\mathrm{DO}^{14} \mathrm{Cp}$ and ${ }^{3} \mathrm{H}$-leucine uptake proportionally to their contribution to community structure. The ${ }^{3} \mathrm{H}$-leucine uptake pattern was roughly similar between the two stations. In the southern basin and at Kabuno Bay station, we found that $85 \%$ and $75 \%$ of all the bacteria taking up ${ }^{3} \mathrm{H}$-leucine belonged to two groups: Betaproteobacteria and Alphaproteobacteria. Accounting together for $42 \%$ and $41 \%$ of the bacterial community abundance, the contribution of these two groups to ${ }^{3} \mathrm{H}-$ leucine uptake was clearly higher than expected from their relative abundance. By contrast, the Bacteroidetes, the Gammaproteobacteria, and the bacterial cells unrelated to any of the bacterial groups investigated in this study

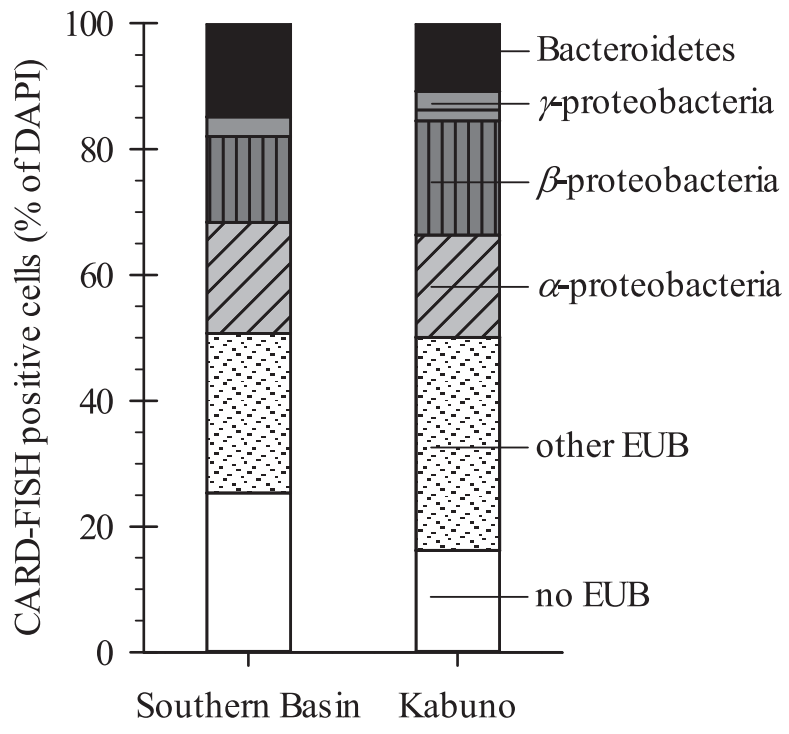

Station

Fig. 6. Relative abundances of heterotrophic prokaryotes analyzed by CARD-FISH and scaled to total DAPI counts in Lake Kivu, in June 2011. "Other EUB" stands for cells identified with the probe mix EUB338-II-III but not detected with any of the probes used, targeting the large phylogenetic groups of Eubacteria: Alpha, Beta, Gammaproteobacteria, and Bacteroidetes. "No EUB" stands for cells counted with DAPI but not identified with the probe mix EUB338-II-III.

(other EUB), were underrepresented in ${ }^{3} \mathrm{H}$-leucine uptake (Fig. 7a). The pattern of $\mathrm{DO}^{14} \mathrm{Cp}$ uptake was different compared to that of ${ }^{3} \mathrm{H}-$ leucine. All the data points were closer to the $1: 1$ line, indicating that the bacterial groups were participating in $\mathrm{DO}^{14} \mathrm{Cp}$ uptake proportionally to their relative contribution to the bacterial community. For instance, Betaproteobacteria and Alphaproteobacteria, the two dominant and overrepresented groups in the portion of the assemblage consuming ${ }^{3} \mathrm{H}$-leucine, accounted for only $47 \%$ and $41 \%$ of cells taking up $\mathrm{DO}^{14} \mathrm{Cp}$ in the southern basin and Kabuno Bay, respectively. Because they contributed $42 \%$ and $41 \%$ to the bacterial community structure, their share in $\mathrm{DO}^{14} \mathrm{Cp}$ consumption was proportional to their in situ abundance.

\section{Discussion}

In this study, we gathered a first consistent set of concurrent measurements of $\mathrm{pPP}$ and $\mathrm{dPP}$ rates in tropical African lakes. The methodology to measure dPP differs largely among different studies available in the literature, and only a few of them account for the heterotrophic uptake of labeled DOCp during the course of the experiment, which can lead to an underestimation of PER. A way to overcome this bias is to observe the kinetics of labeling in the DOC and POC pools and to fit the data with a compartmental organic $\mathrm{C}$ exchange model (Morán et al. 2001; Morán and Estrada 2002).

It has recently been proposed that high DOC release rates, especially in oligotrophic systems, are not sustained by active excretion of healthy phytoplankton, but rather by 

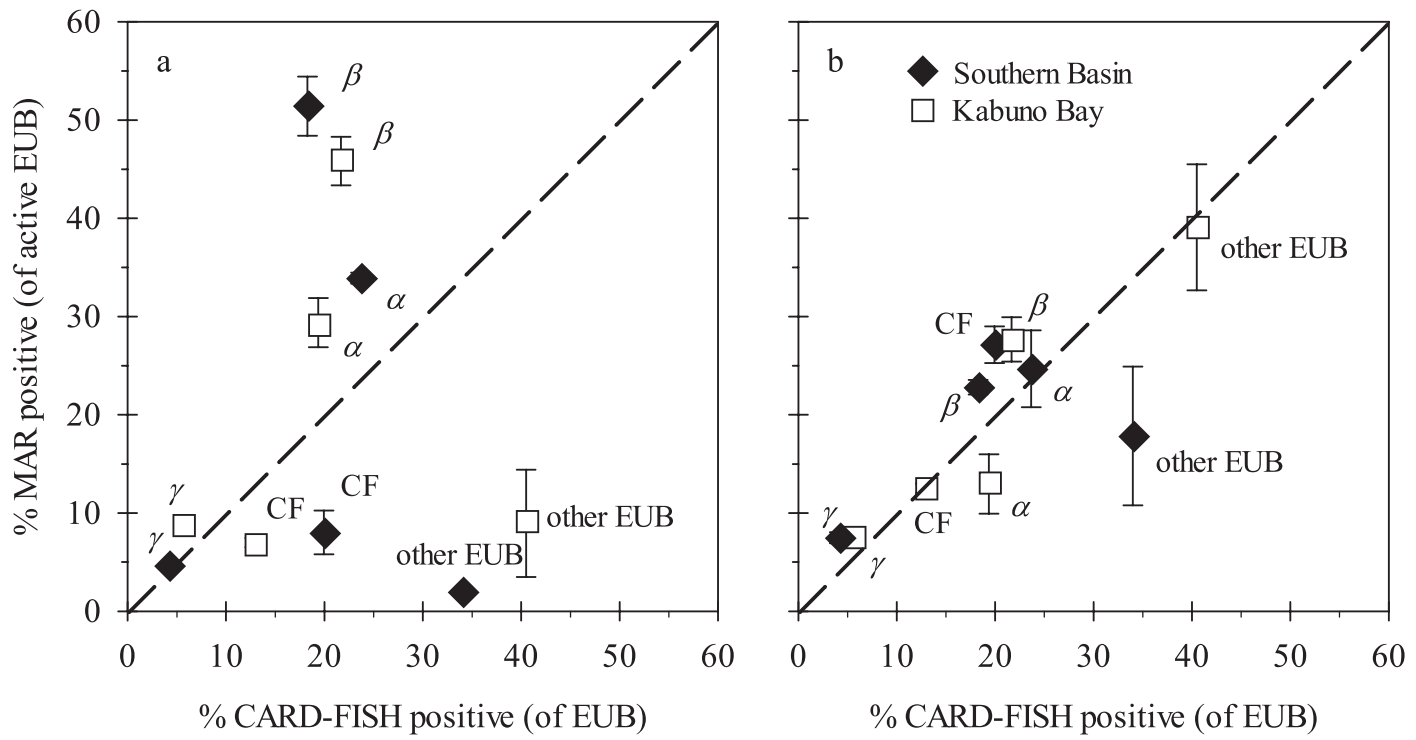

Fig. 7. Relative contribution of each phylogenetic group to the Eubacteria (EUB) community (CARD-FISH positive) against their relative contribution to the (a) ${ }^{3} \mathrm{H}$-leucine or (b) DO ${ }^{14} \mathrm{Cp}$ uptake (MAR positive) in Lake Kivu, in June 2011. Symbols are mean of duplicate measurements, and error bars are the maximum and minimum values. The dashed line is the $1: 1$ line. $\alpha=$ Alphaproteobacteria, $\beta=$ Betaproteobacteria, $\gamma=$ Gammaproteobacteria, $\mathrm{CF}=$ Bacteroidetes, other EUB $=$ cells identified with the probe mix EUB338-II-III but not detected with any of the other probes used.

the lysis of dying cells (Agustí and Duarte 2013). During our short-term experiments, a significant amount of labeled DOCp was released after only $30 \mathrm{~min}$ of incubation, and no lag phase was observed in the appearance of radioactivity in the DOC pool. According to Lancelot (1979), such a lag phase is expected when the specific activity of the intracellular pool of molecules that can be exchanged with the external medium does not immediately reach a stable value. Therefore, the absence of lag phase (Fig. 3a) implies that the excreted compounds originate from a small intracellular pool that has a relatively high turnover rate (Marañón et al. 2004). Based on this observation, it appears unlikely that cell lysis or trophic processes such as zooplankton grazing were the main mechanisms of DOCp release, because then a large amount of non-recent, presumably unlabeled metabolites would have been part of the intracellular pool of molecules fated for release, considerably increasing its size. Instead, it seems to be driven by a purely physiological mechanism of phytoplankton excretion of freshly produced photosynthates (Marañón et al. 2004).

Why do phytoplankton cells actively release photosynthates? Previous studies have shown that high irradiance (Zlotnik and Dubinsky 1989) and nutrient limitation enhance phytoplankton excretion, particularly in P-limited situations (Obernosterer and Herndl 1995; Myklestad 2000). Under high-light conditions, such as in the tropics, photorespiration, the fixation of $\mathrm{O}_{2}$ on ribulose-1,5phosphate catalyzed by ribulose-1,5-bisphosphate carboxylase oxygenase (RubisCO) with glycolate as a byproduct, is an effective protection mechanism against photoinhibition. It keeps the consumption of nicotinamide adenine dinucleotide phosphate and adenosine triphosphate (ATP) at high levels and lowers the saturation of the electron transport chain, preventing the production of reactive oxygen species. An important fraction of this glycolate can be actively excreted by phytoplankton cells to the water (Fogg 1983), where it can be rapidly consumed by heterotrophic prokaryotes (Lau et al. 2007). Besides photorespiration, the active release of photosynthate by phytoplankton cells can be viewed as a mechanism occurring under nutrient limitation, when the synthesis of molecules containing $\mathrm{N}$ or $\mathrm{P}$ is not possible (Wood and Van Valen 1990; Morán et al. 2002). Because of the nutrient limitation, a fraction of the freshly fixed $\mathrm{C}$ is a surplus and is, therefore, excreted. It has also been proposed that DOCp release could be a purely passive diffusion process of molecules across the membrane due to a concentration gradient and, thus, directly proportional to phytoplankton biomass (Bjørnsen 1988; Marañón et al. 2004).

The PER value measured in Lake Kivu (42-64\%) was much higher than the cross-system average of $13 \%$ proposed by Baines and Pace (1991) but was within the large range of values reported for lakes (3-82\%). PER decreased with increasing pPP, the highest value being observed in the oligotrophic Lake Kivu and the lowest in the eutrophic Lake Victoria (Fig. 8). The use of a multiple linear regression model combining log-transformed $\mathrm{I}_{\mathrm{Zm}}$ and $\mathrm{PO}_{4}^{3-}$ to predict PER explained a high amount of the variance (adjusted $r^{2}=0.51$ ) and shows that both independent variables had a significant effect on PER $\left(\mathrm{PER}=-92.13+49.99 \times \log \mathrm{I}_{\mathrm{Zm}}-27.16 \times \log \mathrm{PO}_{4}^{3-} ; p=\right.$ 0.030 for $\log \mathrm{I}_{\mathrm{Zm}} ; p=0.036$ for $\left.\log \mathrm{PO}_{4}^{3-} ; n=11\right)$. No significant correlations were found when using a univariate linear model $(p>0.05)$ to predict PER. Hence, high $\mathrm{I}_{\mathrm{Zm}}$ and low $\mathrm{PO}_{4}^{3-}$ concentration in the mixed layer had a significant combined positive effect on phytoplankton excretion. Overall, these results support the view that environmental factors play an important role in the control of PER in large African lakes. Furthermore, the relationship 


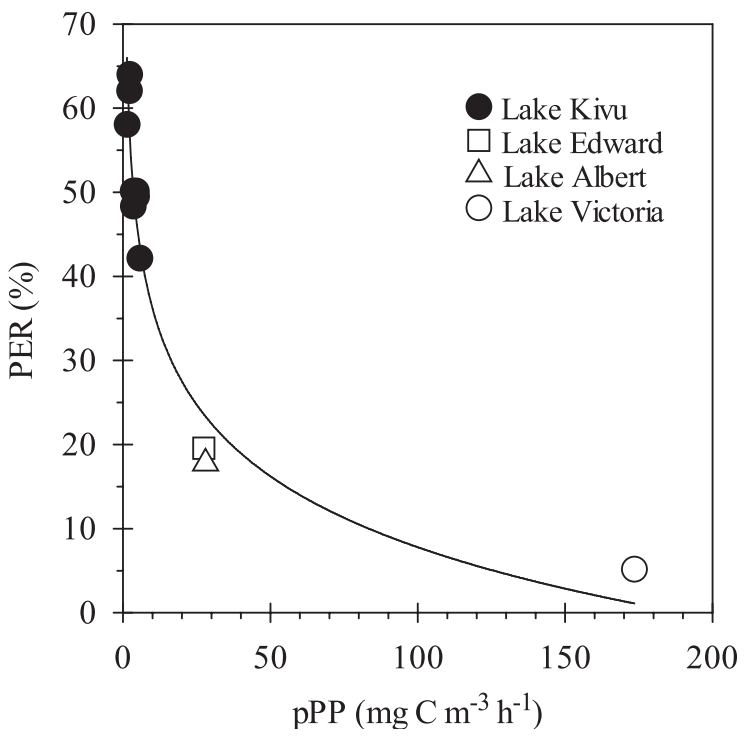

Fig. 8. Relationship between the percentage of extracellular release (PER) and particulate primary production $(\mathrm{pPP})$ in the four lakes studied.

between PER and pPP was nonlinear, because PER tended to level off at a minimum value in the most productive waters. Because the debate around the physiological mechanisms driving phytoplankton excretion remains unresolved (Fogg 1983; Bjørnsen 1988), we hypothesize that the passive diffusion and the transport-mediated mechanisms are not mutually exclusive, but that the dominance of one on the other may change. For instance, we would suggest that passive DOCp leakage across the membrane would be relatively constant, whereas active loss by a transportmediated mechanism would be related to environmental conditions, such as nutrient and light availability. Hence, in tropical oligotrophic waters, under high-light and lownutrient conditions, the transport-mediated mechanism could be the main process responsible for extracellular excretion, but its dominance over the passive diffusion mechanism would decrease along the productivity gradient.

In a review of published dPP values corrected for heterotrophic uptake, Fouilland and Mostajir (2010) found a similar nonlinear inverse relationship between PER and primary production in freshwater temperate lakes (Fig. 9), but the slope of the log-log relationship between dPP and pPP in the African tropical lakes (0.23-0.44, 95\% confidence interval) is significantly lower than the one for temperate lakes $(0.48-0.65,95 \%$ confidence interval; ANCOVA, $\left.f_{1,81}=8.047 ; p<0.01\right)$. This difference indicates that, in unproductive waters, PER is higher in tropical lakes than in their temperate counterparts, consistent with the higher and relatively constant irradiance distinctive of tropical environments. We predict, therefore, that high PER values should be expected in other large oligotrophic tropical lakes, such as Lake Malawi and Lake Tanganyika.

The mean annual BP in the mixed layer of Lake Kivu was $336 \mathrm{mg} \mathrm{C} \mathrm{m}^{-2} \mathrm{~d}^{-1}(n=10$ sampling dates in 2008; Llirós et al. 2012). Bacterial respiration has not been directly measured in Lake Kivu; but, using a range of

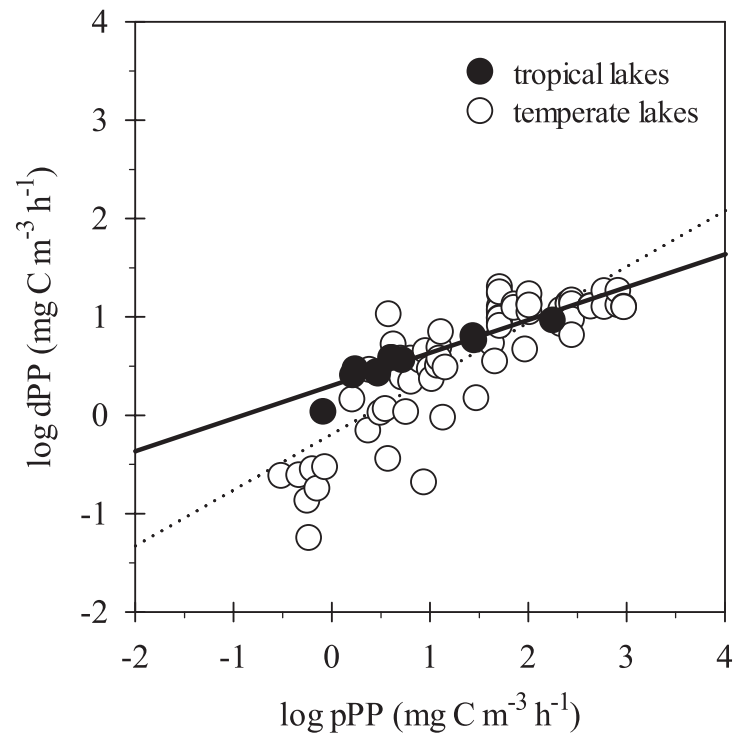

Fig. 9. Relationship between $\log (\mathrm{pPP})$ and $\log (\mathrm{dPP})$ in several African large tropical lakes (solid line, model I regression, our dataset) and several temperate lakes (dotted line, model I regression, data from Fouilland and Mostajir 2010). The tropical lakes regression is described in Table 3, and the temperate lakes regression is $\log (\mathrm{dPP})=-0.57 \log (\mathrm{pPP})-0.19 ; R^{2}=0.71, p<$ $0.0001 ; n=73$.

bacterial growth efficiency (BGE) values expected in tropical systems (10-20\%), the bacterial C demand (BCD; $\mathrm{BCD}=\mathrm{BP} / \mathrm{BGE}$ ) would range between $1680 \mathrm{mg} \mathrm{C} \mathrm{m}^{-2} \mathrm{~d}^{-1}$ and $3360 \mathrm{mg} \mathrm{C} \mathrm{m}^{-2} \mathrm{~d}^{-1}$. The mean phytoplankton pPP in Lake Kivu (620 mg C m${ }^{-2} \mathrm{~d}^{-1}$; Darchambeau et al. 2014) is clearly unable to support the BCD by itself, but the high PER values (42-64\%) reported in this study would allow total phytoplankton production to meet $32-103 \%$ of the $\mathrm{BCD}$ in Lake Kivu. This reasoning can be extended to Lake Tanganyika, where total primary production would sustain 36-117\% of BCD (Table 4). The range of BCD estimates that can be sustained by total phytoplankton production is wide, but it strongly depends on the choice of BGE values. In addition, other processes that were not measured during this study, such as grazing by zooplankton or cell lysis, can significantly contribute to the release of autochthonous DOC.

DOCp is a highly complex pool of diverse molecules whose exact chemical natures are unknown. Carbohydrates of various sizes should be predominant in the excreted products (Myklestad 2000). It has recently been shown that the nature of the DOCp depends on phytoplankton community composition (Sarmento et al. 2013). In the large African lakes investigated, the DOCp standing stock was relatively small compared to the high dPP rates observed, and the turnover times of the DOCp were, therefore, short (Table 2). In other words, the consumption of DOCp was tightly coupled to its production, and only a small amount of DOCp accumulated in the water. This suggests that the DOCp pool was mainly composed of labile molecules that were preferentially assimilated by heterotrophic prokaryotes over other organic C sources. These observations highlight the importance of a direct 
Table 4. Estimates of bacterial carbon demand (BCD) using a range of bacterial growth efficiencies (BGE) and bacterial production (BP) data obtained from the literature. Estimates of the fraction of the $\mathrm{BCD}$ met by phytoplankton production ( $\mathrm{PP}=$ $\mathrm{dPP}+\mathrm{pPP}$ ) using the range of PER measured in Lake Kivu during this study.

\begin{tabular}{lcc}
\hline \hline \multicolumn{1}{c}{ Variable } & Lake Kivu & Lake Tanganyika \\
\hline $\mathrm{BCD}\left(\mathrm{mg} \mathrm{C} \mathrm{m}^{-2} \mathrm{~d}^{-1}\right)$ & $1680-3360$ & $1550-3100$ \\
$\mathrm{BGE}(\%)$ & $10-20$ & $10-20$ \\
$\mathrm{BP}\left(\mathrm{mg} \mathrm{C} \mathrm{m}^{-2} \mathrm{~d}^{-1}\right)$ & $336^{*}$ & $310 \dagger$ \\
pPP $\left(\mathrm{mg} \mathrm{C} \mathrm{m}^{-2} \mathrm{~d}^{-1}\right)$ & $620 \dagger$ & $654 \dagger$ \\
PER (\%) & $42-64 \S$ & $0.36-1.17$ \\
PP/BCD & $0.32-1.03$ & 03 \\
\hline
\end{tabular}

* Llirós et al. 2012.

$\uparrow$ Sténuite et al. 2009.

\$ Darchambeau et al. 2014.

$\S$ This study.

transfer of organic matter from phytoplankton to bacterioplankton in Lake Kivu.

The fraction of cells active in the uptake of leucine after $5 \mathrm{~h}$ of incubation (average 19\%) was close to the range of values of metabolically active cells reported in the literature (20-40\%, del Giorgio and Gasol 2008), but the fraction of active cells in DOCp uptake (average 11.5\%) was low compared to this range. However, these studies used lowmolecular-weight, very labile molecules as tracers, but the DOCp pool presumably comprises higher-molecular-weight substrates that require more complex enzymatic pathways and that are, therefore, harder to assimilate in short incubations. Additionally, the activity of some light-sensitive heterotrophic prokaryotes might have been inhibited by the high light irradiance during our incubations. Also, the labeled $\mathrm{DO}^{14} \mathrm{Cp}$ was diluted with nonlabeled and equally labile compounds, which decreased the sensitivity of the technique at this range of incubation times.

In contrast to earlier studies that used standard labeled molecules, such as leucine, ATP, or glucose (Alonso-Sáez and Gasol 2007), our MAR-FISH results show that all different phylogenetic groups of heterotrophic prokaryotes were involved in the uptake of molecules belonging to the uncharacterized pool of $\mathrm{DO}^{14} \mathrm{Cp}$. The high abundance and activity of members of the Betaproteobacteria group is not surprising; their abundance has been found to be positively related with the amount of algal-derived substrates (Simek et al. 2008; Paver et al. 2012), and they are usually ubiquitous in freshwaters. The relatively high abundance of Alphaproteobacteria and Bacteroidetes members is more difficult to interpret. Members of these groups are generally not abundant in freshwaters but seem to be effectively resistant to eukaryote predation (Newton et al. 2011); however, bacterivory pressure has never been estimated in Lake Kivu. Overall, our observations support the idea that the metabolic ability to process labile algal-derived dissolved organic matter is widespread among broad prokaryote groups (Landa et al. 2013). Furthermore, it is possible that the diversity of molecules excreted by the phytoplankton community present in Lake Kivu can support a variety of ecological niches for heterotrophic prokaryotes, thereby allowing them to avoid direct resource competition. It was, indeed, recently shown that the composition of the extracellular release of dissolved free amino acids by phytoplankton was species dependent (Sarmento et al. 2013).

${ }^{3} \mathrm{H}$-leucine is a widely used tracer for BP measurements (Kirchman et al. 1985). This method requires a parallel estimate of the leucine-to-C conversion factor, defined as the yield of bacterial biomass per unit of leucine incorporated. Nevertheless, a difference in ability to take up leucine among different phylogenetic groups of prokaryotes has been reported (Pérez et al. 2010), and community composition could affect leucine-to-C conversion factor estimates (Alonso-Sáez et al. 2010). To our best knowledge, our study is the first to compare the uptake pattern of ${ }^{3} \mathrm{H}$-leucine to the uptake pattern of $\mathrm{DO}^{14} \mathrm{Cp}$ produced by a natural phytoplankton community. In Lake Kivu, members of Alphaproteobacteria, Betaproteobacteria, and Bacteroidetes were involved in $\mathrm{DO}^{14} \mathrm{Cp}$ uptake proportionally to their abundance, but they differed strongly in their ability to take up ${ }^{3} \mathrm{H}$-leucine. This discrepancy suggests that leucine may not be a good representative of other naturally occurring, but more complex, organic C sources, such as DOCp.

\section{Acknowledgments}

We thank Boniface Kaningini, Pascal Isumbisho, and Pascal Masilya (Institut Supérieur Pédagogique, Bukavu, Democratic Republic of Congo), Laetitia Nyinawamwiza (National University of Rwanda, Rwanda), William Okello (National Fisheries Resources Research Institute, Jinja, Uganda), and their respective teams for logistic support during the cruises; Bruno Leporcq, Marc-Vincent Commarieu, and Irene Forn for laboratory assistance; and Sébastien Knops, Xavier Libert, and Mélodie Schmitz for help during fieldwork. We also thank Eric Fouilland for providing his dataset, and the associate editor (J. Melack) and four anonymous referees for constructive comments on this manuscript. This work was funded by the "East African Great Lake Ecosystem Sensitivity to Changes" (EAGLES, SD/AR/02A) project from the Belgian Federal Science Policy Office (BELSPO, Belgium), the "Cycle du Carbone et des Nutriments au Lac Kivu" (CAKI, contract 2.4.598.07), and "Microbial Diversity and Processes in Lake Kivu" (MICKI, contract 2.4.515.11) projects from the "Fonds National de la Recherche Scientifique" (FNRS, Belgium), and project (CGL2010-11556-E) from the Spanish Ministry for Science and Technology. This publication contributes to the European Research Council (ERC) starting grant project "African river basins: Catchment-scale carbon fluxes and transformations" (AFRIVAL, 240002). H.S. benefited from fellowships from the Spanish "Ministerio de Educación y Ciencia" (JCI-2008-2727) and the Brazilian National Council for Scientific and Technological Development (CNPq) and Foundation for Research Support of the State of São Paulo (FAPESP).

\section{References}

Agustí, S., And C. M. Duarte. 2013. Phytoplankton lysis predicts dissolved organic carbon release in marine plankton communities. Biogeosciences 10: 1259-1264, doi:10.5194/bg-10-12592013

Alonso-SÁez, L., And J. M. Gasol. 2007. Seasonal variations in the contributions of different bacterial groups to the uptake of low-molecular-weight compounds in northwestern Mediterranean coastal waters. Appl. Environ. Microbiol. 73: 3528-3535, doi:10.1128/AEM.02627-06 
, J. Pinhassi, J. Pernthaler, and J. M. Gasol. 2010. Leucine-to-carbon empirical conversion factor experiments: Does bacterial community structure have an influence? Environ. Microbiol. 12: 2988-2997, doi:10.1111/j.14622920.2010.02276.x

American Public Health Association. 1998. Standard methods for the examination of water and wastewater, 20th ed. APHA.

Baines, S. B., AND M. L. PACE. 1991. The production of dissolved organic matter by phytoplankton and its importance to bacteria: Patterns across marine and freshwater systems. Limnol. Oceanogr. 36: 1078-1090, doi:10.4319/lo.1991.36.6.1078

BuøRnsen, P. K. 1988. Phytoplankton exudation of organic matter: Why do healthy cells do it? Limnol. Oceanogr. 33: 151-154, doi:10.4319/1o.1988.33.1.0151

Borges, A. V., G. Abril, B. Delille, J.-P. Descy, and F. Darchambeau. 2011. Diffusive methane emissions to the atmosphere from Lake Kivu (Eastern Africa). J. Geophys. Res. 116: G03032, doi:10.1029/2011JG001673

Cole, J. J., S. Findlay, And M. L. Pace. 1988. Bacterial production in fresh and saltwater ecosystems: A cross-system overview. Mar. Ecol. Prog. Ser. 43: 1-10, doi:10.3354/meps043001

, G. E. Likens, And D. L. Strayer. 1982. Photosynthetically produced dissolved organic carbon: An important carbon source for planktonic bacteria (Mirror Lake, New Hampshire, algae). Limnol. Oceanogr. 27: 1080-1090, doi:10.4319/lo.1982.27.6.1080

Darchambeau, F., H. Sarmento, and J.-P. Descy. 2014. Primary production in a tropical large lake: The role of phytoplankton composition. Sci. Total Environ. 473: 178-188, doi:10.1016/ j.scitotenv.2013.12.036

del Giorgio, P. A., And J. M. Gasol. 2008. Physiological structure and single-cell activity in marine bacterioplankton, p. 243-298. In D. L. Kirchman [ed.], Microbial ecology of the oceans, 2nd ed. John Wiley and Sons.

FoGG, G. E. 1983. The ecological significance of extracellular products of phytoplankton photosynthesis. Botanica Marina 26: 3-14, doi:10.1515/botm.1983.26.1.3

Fouilland, E., AND B. MostajIR. 2010. Revisited phytoplanktonic carbon dependency of heterotrophic bacteria in freshwaters, transitional, coastal and oceanic waters. FEMS Microbiol. Ecol. 73: 419-429, doi:10.1111/j.1574-6941.2010.00896.x

Frankignoulle, M., AND A. V. Borges. 2001. Direct and indirect pCO2 measurements in a wide range of $\mathrm{pCO} 2$ and salinity values (the Scheldt estuary). Aquat. Geochem. 7: 267-273, doi:10.1023/A:1015251010481

Guildford, S. J., And R. E. Hecky. 2000. Total nitrogen, total phosphorus, and nutrient limitation in lakes and oceans: Is there a common relationship? Limnol. Oceanogr. 45: 1213-1223, doi:10.4319/lo.2000.45.6.1213

Kirchman, D., E. K'nees, and R. Hodson. 1985. Leucine incorporation and its potential as a measure of protein synthesis by bacteria in natural aquatic systems. Appl. Environ. Microbiol. 49: 599-607.

LANCELOT, C. 1979. Gross excretion rates of natural marine phytoplankton and heterotrophic uptake of excreted products in the southern North Sea, as determined by short-term kinetics. Mar. Ecol. Prog. Ser. 1: 179-186, doi:10.3354/meps001179

LANDA, M., AND OTHERs. 2013. Phylogenetic and structure response of heterotrophic bacteria to dissolved organic matter of different chemical composition in a continuous culture study. Environ. Microbiol., doi:10.1111/1462-2920.12242

Lau, W. W., R. G. Keil, and E. V. Armbrust. 2007. Succession and diel transcriptional response of the glycolate-utilizing component of the bacterial community during a spring phytoplankton bloom. Appl. Environ. Microbiol. 73: 2440-2450, doi:10.1128/AEM.01965-06
Lehman, J. T., A. H. Litt, R. Mugidde, and D. A. Lehman. 1998. Nutrients and plankton biomass in the rift lake sources of the White Nile: Lakes Albert and Edward, p. 157-172. In J. T. Lehman [ed.], Environmental change and response in East African lakes. Kluwer Academic Publishers.

Llirós, M., AND OTHERs. 2012. Microbial ecology of Lake Kivu, p. 85-105. In J.-P. Descy, F. Darchambeau, and M. Schmid [eds.], Lake Kivu: Limnology and biogeochemistry of a tropical great lake. Springer.

Marañón, E., P. Cermeno, E. Fernández, J. Rodriguez, and L. ZABALA. 2004. Significance and mechanisms of photosynthetic production of dissolved organic carbon in a coastal eutrophic ecosystem. Limnol. Oceanogr. 49: 1652-1666, doi:10.4319/ lo.2004.49.5.1652

Millero, F. J., T. B. Graham, F. Huang, H. Bustos-Serrano, And D. Pierrot. 2006. Dissociation constants of carbonic acid in sea water as a function of salinity and temperature. Mar. Chem. 100: 80-94, doi:10.1016/j.marchem.2005.12.001

Morán, X. A. G., And M. Estrada. 2002. Phytoplanktonic DOC and POC production in the Bransfield and Gerlache Straits as derived from kinetic experiments of ${ }^{14} \mathrm{C}$ incorporation. Deep Sea Res. II 49: 769-786, doi:10.1016/S0967-0645(01)00123-0 , J. M. Gasol, C. Pedrós-Alió, and M. Estrada. 2001 Dissolved and particulate primary production and bacterial production in offshore Antarctic waters during austral summer: Coupled or uncoupled? Mar. Ecol. Prog. Ser. 222: 25-39, doi:10.3354/meps222025

Myklestad, S. M. 2000. Dissolved organic carbon from phytoplankton, p. 111-148. In P. Wangersky [ed.], Marine chemistry. Springer.

Newton, R. J., S. E. Jones, A. Eiler, K. D. McMahon, and S. Bertilsson. 2011. A guide to the natural history of freshwater lake bacteria. Microbiol. Mol. Biol. Rev. 75: 14-49, doi:10.1128/MMBR.00028-10

Obernosterer, I., and G. J. Herndl. 1995. Phytoplankton extracellular release and bacterial growth: Dependence on the inorganic N : P ratio. Mar. Ecol. Prog. Ser. 116: 247-257, doi:10.3354/meps 116247

Paver, S. F., C. E. Nelson, and A. D. Kent. 2012. Temporal succession of putative glycolate-utilizing bacterioplankton tracks changes in dissolved organic matter in a high-elevation lake. FEMS Microbiol. Ecol. 83: 541-551, doi:10.1111/1574-6941. 12012

Pérez, M. T., P. Hörtnagl, and R. Sommaruga. 2010 Contrasting ability to take up leucine and thymidine among freshwater bacterial groups: Implications for bacterial production measurements. Environ. Microbiol. 12: 74-82, doi:10.1111/j.1462-2920.2009.02043.x

- AND R. Sommaruga. 2006. Differential effect of algal- and soil-derived dissolved organic matter on alpine lake bacterial community composition and activity. Limnol. Oceanogr. 51: 2527-2537, doi:10.4319/1o.2006.51.6.2527

Riley, G. A. 1957. Phytoplankton of the north central Sargasso Sea, 1950-52. Limnol. Oceanogr. 2: 252-270.

Sarmento, H., And J. M. Gasol. 2012. Use of phytoplanktonderived dissolved organic carbon by different types of bacterioplankton. Environ. Microbiol. 14: 2348-2360, doi:10.1111/j.1462-2920.2012.02787.x

, F. Unrein, M. Isumbisho, S. Sténuite, J. M. Gasol, and J.P. DesCy. 2008. Abundance and distribution of picoplankton in tropical, oligotrophic Lake Kivu, eastern Africa. Freshw. Biol. 53: 756-771, doi:10.1111/j.1365-2427.2007.01939.x

— AND OTHERS. 2013. Selective influences of dissolved free amino acid release by phytoplankton on bacterioplankton communities. Limnol. Oceanogr. 58: 1123-1135, doi:10.4319/ lo.2013.58.3.1123 
Simek, K., K. Hornak, J. Jezbera, J. Nedoma, P. Znachor, J. Hejzlar, and J. Sed'a. 2008. Spatio-temporal patterns of bacterioplankton production and community composition related to phytoplankton composition and protistan bacterivory in a dam reservoir. Aquat. Microb. Ecol. 51: 249-262, doi:10.3354/ame01193

STÉNUITE, S., AND OTHERS. 2009. Abundance and production of bacteria, and relationship to phytoplankton production, in a large tropical lake (Lake Tanganyika). Freshw. Biol. 54: 1300-1311, doi:10.1111/j.1365-2427.2009.02177.x

VerbeKe, J. 1957. Exploration hydrobiologique des lacs Kivu, Edouard et Albert (1952-1954). Resultats Scientifiques. V. III, Fascicule 1: Recherche écologique sur la faune des grands lacs de l'est du Congo Belge. Royal Institute of Natural Sciences of Belgium, Brussels. [Hydrobiological exploration of Lakes Kivu, Edward and Albert (1952-1954). Scientific Results. V. III, Part 1: Research about the ecology of the fauna in the large lakes in the East Belgian Congo.]
Wiebe, W. J., And D. F. Smith. 1977. Direct measurement of dissolved organic carbon release by phytoplankton and incorporation by microheterotrophs. Mar. Biol. 42: 213-223, doi:10.1007/BF00397745

Wood, A., And L. M. Van Valen. 1990. Paradox lost? On the release of energy-rich compounds by phytoplankton. Mar. Microb. Food Webs 4: 103-116.

Zlotnik, I., And Z. Dubinsky. 1989. The effect of light and temperature on DOC excretion by phytoplankton. Limnol. Oceanogr. 34: 831-839, doi:10.4319/1o.1989.34.5.0831

Associate editor: John M. Melack

Received: 16 December 2013 Accepted: 16 April 2014 Amended: 21 April 2014 